\title{
Psychosis as a Zoonosis: Clues from Covid
}

\subsection{Diseases from Animals}

This book proposes that an infectious agent may be transmitted from animals, specifically cats, to humans and then cause some cases of psychosis. As such, the thesis includes two major problems. First, most people do not think of infectious agents as being transmitted from animals to humans. Second, most people do not think of human psychosis, including diseases such as schizophrenia and bipolar disorder, as being caused by infectious agents. Thus we must first resolve these two issues before we can expect to make any headway on the overriding thesis.

Except for a few diseases such as rabies, we do not generally think of human diseases as being transmitted to us from animals. The Covid pandemic of 2020-2021 reminded us forcefully that such transmission can indeed take place with devastating consequences. The coronavirus which causes covid most likely originated in bats although it may have passed through other animals before reaching us.

In fact, it has been clearly established that the majority of human diseases are caused by infectious agents which have been transmitted to us from animals. Some of them were transmitted in the distant past, such as the hepatitis virus that we acquired from our primate forefathers in the process of evolution. Other infectious agents, such as the bacteria that cause anthrax and brucellosis, were transmitted to humans during our millions of years of hunting and butchering animals. During the agricultural revolution approximately 10,000 years ago, we domesticated a variety of animals and, in the process, acquired a variety of diseases. For example, it is suspected that we acquired the microbe that causes stomach ulcers from sheep, tuberculosis from goats, whooping cough from pigs, measles from cattle, glanders from horses, smallpox from water buffalo, typhoid fever from chickens, and influenza from ducks. We sometimes romanticize the past as having been more free of diseases than the present, but in reality the opposite was true. In the Garden of Eden, Adam may have had herpes virus cold sores, Eve may have had hepatitis, and the snake was almost certainly carrying salmonella bacteria [1]. 
It is not only that human diseases were acquired from animals in the past; Covid has confirmed that the process is ongoing. In 2001 Scottish researchers listed 175 infectious agents known to cause diseases in humans. Of these, 132, or $75 \%$, are known to be transmitted from animals. In 2004 the director of the Centers for Disease Control and Prevention (CDC) noted that " 11 of the last 12 emerging infectious disease that we're aware of in the world, that have human health consequences, have probably arisen from animal sources." In summary, it seems very plausible that any disease affecting humans could have been transmitted from animals $[2,3]$.

\subsection{Bats and Rats, but Please, Not Cats}

The idea that bats or rats can cause human disease because of the infectious agents that they carry is one thing, but the idea that cats can be similarly responsible is quite another. In the United States, according to the 2010 census, 32\% of households owned at least one cat. The total number of owned cats in the United States is thought to total approximately 90 million. In addition, there are estimated to be anywhere from 30 to 80 million feral cats, with the Humane Society suggesting a median estimate of 50 million. That would put the total number of cats in the United States at 140 million; since there are estimated to be a total of approximately 600 million cats in the world, the United States would have almost one quarter of them.

Cats are not like bats or rats or other animals. In recent years their status has changed from being merely animals to becoming human companions. For example, in Colorado, legislation was introduced to change their legal status from "property" to "companion." In Mississippi a man petitioned the Department of Agriculture to allow him to use his food stamps to buy food for his pets. In Minnesota a company allows employees to take a week of "paw-ternity" leave and work at home when they acquire a new cat or dog. More than 30 states now require emergency officials to have plans for pet evacuations in disasters. Expenditures by American families on their pets in 2016 surpassed $\$ 60$ billion, approximately the same as the gross national product of Afghanistan, Bolivia, Nepal, or Uganda [4-8].

One consequence of viewing cats as human companions rather than as animals is the intimacy it implies. Thus it has been reported that $75 \%$ of pet cats in the United States are allowed to sleep on the beds of their owners- $62 \%$ on the beds of adults and $13 \%$ on the beds of children. In both England and France, $45 \%$ of cats sleep on their owners' beds, and in the Netherlands, the figure is $62 \%$. Such intimacy makes it more likely that any infectious agent being carried by the cat will be transmitted to the cat's owner, and in fact studies have identified cases of bubonic plague, cat scratch disease, and other diseases that have been transmitted to humans by cats which slept with them [9].

As cats transitioned from being merely animals to becoming human companions in the latter half of the twentieth century and early years of the twenty-first century, 
cats experienced a profound increase in popularity. A harbinger of this change was Catwoman, who first appeared in the Batman comics in 1940. Initially, Catwoman was a villain, but by the 1970s, she had taken on a more nuanced role, occasionally acting as Batman's helper and even as his love interest. Catwoman drove a cat-illac and used a bullwhip as her weapon of choice. In the Batman movies of 1966, 1992, 2004, and 2012, Catwoman was played by Eartha Kitt, Michelle Pfeiffer, Halle Berry, and Ann Hathaway.

Another comic strip character that has popularized cats is Garfield, an orange, fuzzy tabby cat who debuted in 1978. Garfield is owned by Jon Arbuckle who also has a beagle named Odie, and it is with Jon and Odie that Garfield mostly interacts. Garfield represents human weaknesses insofar as he is overweight, eats too much (he is especially fond of lasagna), disdains any exercise or work, hates Mondays, and is self-centered. By 2002, Garfield had become the most widely syndicated comic strip in the world. This popularity was developed into multiple movies and television primetime specials, at least four of which won Emmy awards, as well as into a Saturday morning cartoon series. It has also spawned a variety of Garfieldassociated merchandise, including clothing, toys, videogames, books, dolls, and credit cards. Other movies that helped to popularize cats include "That Darn Cat" (1965) and "Aristocats" (1978), which was the last film approved by Walt Disney prior to his death $[10,11]$.

A major advance in the promotion of cats was the musical by that name. Written by Andrew Lloyd Webber, it was based on T.S. Eliot's Old Possum's Book of Practical Cats. It opened in London in 1981 and ran continuously for 21 years, setting a record for being the longest running musical until it was surpassed by "Les Misérables." "Cats" opened in New York in 1982 and ran continuously for 18 years, also setting a record until surpassed by "The Phantom of the Opera." "Cats" has been translated into more than 20 languages and produced in 34 countries in addition to the United States. Rum Tum Tugger, Old Deuteronomy, and the other cats are now known worldwide, many having their own entry on Wikipedia.

Despite the popularity of cats achieved by comics, movies, and a musical, nothing has promoted the image of cats as much as the Internet. According to Wikipedia, as of 2015, there were over two million cat videos on YouTube and as many as 6.5 billion total cat pictures on the Internet. Indeed, cats have been said to be the "unofficial mascot of the Internet." An Internet celebrity such as "Grumpy Cat" had more than 20 million views of its original YouTube video and 4 million followers on Instagram and had its own agent who signed advertising deals. It was featured on the front page of the Wall Street Journal and, when it died in 2019, was given an obituary with picture in The New York Times [12-14].

Given this status, it is difficult to think of cats in the same category as bats and rats as carriers of infectious agents that cause human disease. But that is indeed the case. The most extensive work on this question has been carried out by Dr. Marie McIntryre and her colleagues at the University of Liverpool. They created a public database, the Enhanced Infectious Diseases Database (EID-2), that includes 273 
infectious agents that have been identified in cats, of which 151 are known to be shared with humans. These include infectious agents causing diseases such as the following:

- Viral: cowpox, rabies

- Bacterial: anthrax, campylobacter enteritis, cat scratch disease, diphtheria, listeriosis, Lyme disease, plague, salmonellosis, shigellosis, streptococcal infection, tularemia, yersiniosis

- Rickettsial: Q fever

- Spirochetal: leptospirosis

- Fungal: ringworm, blastomycosis, sporotrichosis

- Protozoal: amebic dysentery, giardiasis, toxoplasmosis

- Worms: hydatid disease, cutaneous larva migrans, visceral larva migrans

- Arachnids: scabies

Several of these diseases are serious and not uncommon; for example, 60 cases of cat scratch disease were diagnosed in the state of Connecticut in a 13-month period [15-17].

The fact that cats can become infected with the coronavirus that causes Covid disease is simply one more example of an infectious agent that can be carried by cats. And it was not surprising, given the fact that cats are known to be infected with a related feline coronavirus. During the initial Covid outbreak in New York City, it quickly became apparent that the cat family was susceptible to the disease when three lions in the Bronx Zoo were diagnosed with Covid, apparently having become infected by the zookeepers. Later it was shown that a tiger and a snow leopard were also infected. Since that time it has been shown that both cats and dogs can become infected, although both show only mild symptoms. In one study it was reported that in households in which a person was infected with Covid, $24 \%$ of the household cats and $15 \%$ of the dogs were also infected. It has also been shown that infected cats can pass the Covid virus to other cats. To date, however, there is no evidence that cats transmit the virus back to uninfected humans. This stands in contrast to the situation on mink farms where mink are raised commercially for their pelts; not only do mink become severely infected and even die from Covid, but they also have been proven to spread the virus back to humans. Because the virus was also mutating in the mink, causing concern that it might become resistant to the vaccines, the government of Denmark abolished all mink farming in that country [18-20].

\subsection{The Origin of Cats}

Cats in one form or another have been around for 25 million years. Thus they have had plenty of time to acquire infectious agents, some of which took up permanent residence. One such infectious agent is Toxoplasma gondii which will be discussed in the following chapter. Among the most successful early members of the cat family were saber tooth cats, one of which is incorrectly referred to as a saber tooth 
tiger. Modern tigers, along with leopards, jaguars, and lions, all evolved within the past 2 million years. Wildcats (Felis silvestris) also separated from the other felids about 2 million years ago. The European wildcat (Felis silvestris silvestris) spread widely across Europe, including the British Isles at the time when it was still connected to Europe by a land bridge. The European wildcat is now found only in sparsely inhabited regions of Europe, including Northern Scotland. The African wildcat (Felis silvestris lybica) was widespread in Northern Africa and Southwest Asia and is the only wildcat that has ever been domesticated. It can and does interbreed with European wildcats. Three other species of wildcats are found in Southern Africa and Asia.

Following the agricultural revolution approximately 10,000 years ago, the first farmers in Southwest Asia began storing grain which attracted rodents. The African wildcat was plentiful in that region and, attracted by the rodents, began hanging around the grain storage areas. The farmers, in turn, tolerated the wildcats since they were providing some protection for their grain. We speak of the wildcats as having become domesticated, but even today some people would argue that the term "domesticated cats" is a contradiction in terms. The important point is that the earliest relationship between cats and humans was a distant one with little direct contact. The relationship was probably similar to how we think of feral cats today.

After farming had become established in Southwest Asia, it slowly spread. Farmers reached Southeast Europe by 8000 years ago, Central Europe by 7000 years ago, and Great Britain by 6000 years ago. As they moved westward, the farmers encountered the original settlers, modern Homo sapiens who had migrated out of Africa about 60,000 years ago and reached Europe by 45,000 years ago, and the two groups intermixed. The African wildcats followed the migratory farmers to Europe and apparently became increasingly domesticated over time. This explains why the remains of what appear to have been domesticated cats have been found in Europe, including in South West England dated to $250 \mathrm{BCE}$, prior to the arrival of Roman soldiers and traders [21].

In addition to spreading westward from Southwest Asia, farming also spread south into Egypt, beginning about 6500 years ago. Since African wildcats were indigenous to Egypt, they also killed the rodents there, thus protecting the grain. Egyptians deified many animals, including the bull, ibis, and crocodile, so it is not surprising that they also deified cats. Egyptians also tamed many animals and kept them as pets, including monkeys and hyenas, so it is also not surprising that they tamed cats. Originally, the Egyptian sacred cats were associated with a minor local deity, Bastet, who was the goddess of fertility in Bubastis, a city in Lower Egypt. However, 2950 years ago, in the 22nd Dynasty, Bubastis was made the capital of Egypt, and Bastet, as a cat-headed goddess, became much more widely worshipped. Later, Bastet became associated with Isis who was one of the principal Egyptian deities. It was this association that ultimately led to a widespread belief that cats were evil and agents of Satan, as will be discussed in Chap. 3.

It should be noted that cats were not associated with evil in ancient Egypt. On the contrary, they were depicted in temple drawings as being part of the household, often sitting under a chair or being fed from the dinner table. Herodotus, who toured 
Egypt 2500 years ago, "reported that Bastet's temple in Bubastis was the most attractive in the whole country and her annual festival the most joyous and popular." He also noted that "when a house was on fire the Egyptians were more anxious to save their cats than their property" $[22,23]$.

The importance of cats in Egypt was apparently unique in the ancient world. There is no mention of them in the Old or New Testament, and they played a minor role in ancient Greece and Rome. Cats appear occasionally on Greek vases and Roman mosaics, including a mosaic from Pompeii, now in the Naples Museum, depicting a cat hunting birds in the marshes. But for rodent control, the Romans preferred ferrets, and as pets they strongly preferred dogs. In his book Classical Cats, Donald Engels noted: "Many tombstones were erected by bereaved Romans to their pet dogs, but none are known for cats" [24].

\subsection{Infectious Agents and Psychosis}

The second major problem associated with the thesis of this book is that most people are unaware that psychosis can be caused by infectious agents. This is especially true for viruses. Herpes simplex virus, for example, usually causes cold sores around the mouth but occasionally gets in the brain and causes psychosis that may look identical to schizophrenia or bipolar disorder. Other herpes viruses, such as the cytomegalovirus and the Epstein-Barr virus, may also occasionally cause psychosis. One of the best-known causes of infectious psychosis is the influenza virus. During the pandemic of what was called Russian influenza in 1889-1892 and again during the pandemic of 1918-1919, cases of psychosis following infection were widely described in individuals who had no previous psychiatric history. Although viruses are the most common cause of psychosis among infectious agents, others can do so also. The spirochete that causes syphilis, for example, was said to be responsible for up to $10 \%$ of the psychosis cases in some psychiatric hospitals prior to the introduction of penicillin. The parasite Toxoplasma gondii can also cause psychosis, as will be described in the next chapter [25].

The Covid pandemic of 2020-2021, caused by a coronavirus, provided a dramatic reminder that infectious agents can cause psychosis as well as a variety of other psychiatric and neurological symptoms. Previous studies had shown that other coronaviruses could cause psychosis, so this development was not a total surprise. A report summarizing the first 42 cases of Covid-related psychosis concluded that "already it is clear that infected patients can exhibit a range of neuropsychiatric symptoms." There appeared to be no relationship between the severity of the Covid symptoms and whether or not the patient developed psychosis. A preliminary study from England reported that there had been a $10 \%$ increase in cases of new onset psychosis in 2020 compared to 2019. More definitive studies will be forthcoming and will clarify the true incidence of psychosis associated with Covid disease [26, 27].

Additional evidence suggesting that infectious agents cause some cases of psychosis comes from national case registers in the Scandinavian countries. One study 
found an almost fivefold increase in adult schizophrenia in individuals who had had a viral infection of their central nervous system as children. A second study reported a $60 \%$ increase in the risk of schizophrenia for individuals who had been hospitalized for any infection. Consistent with such findings are multiple studies that report evidence of inflammation in individuals with schizophrenia. Such evidence includes pro-inflammatory markers such as cytokines and c-reactive protein as well as evidence of microglial activation, all consistent with an infectious process [28-31].

Yet another suggestion that psychosis is associated with infectious agents comes from genetic studies. Among all the reported findings from studies of the genetics of schizophrenia, one finding stands out as the strongest. An area on chromosome 6 is known as the major histocompatibility complex (MHC) and encodes more than 400 genes. A major function of these genes is to regulate the body's immune response, including its response to infectious agents. In genome-wide association studies of individuals with schizophrenia, the activation of the MHC complex has been the single most prominent and replicated finding. This is the part of the genome that would be expected to be activated by an infectious agent. In summary, based on multiple existing studies, it seems plausible that an infectious agent can cause a brain disease such as schizophrenia [32].

Although infectious agents were probably the most common cause of cases of psychosis in history, they were not the only cause. Another cause was brain trauma. Hominins have been beating each other over the head with clubs for as long as hominins have existed, and studies have shown that one of the consequences of head injuries is psychotic symptoms. For example, a follow-up of men who sustained severe head injuries in the Russo-Finnish war, at the onset of World War II, reported that psychotic symptoms occurred in 5\% of cases. Epilepsy, which can also be caused by head trauma, is another ancient medical condition that may exhibit psychotic symptoms, especially if the temporal lobe of the brain is involved [33-35].

As long as hominins have existed, there have also been periods of severe food shortages and consequent starvation. One syndrome associated with food shortage, specifically an insufficient intake of niacin, is pellagra which may include symptoms of mania, hallucinations, and catatonia. Another ancient food-related cause of psychosis is ergot poisoning caused by a fungus that may infect food supplies, especially grains. Its symptoms may include mania and psychosis; outbreaks often occur in epidemics as groups of people are exposed to a common infected food supply. In the Middle Ages, ergotism was well known and referred to as Saint Anthony's fire.

Infections of the brain, head trauma, epilepsy, pellagra, and ergotism were probably the most common but not the only causes of madness in history. Others include genetic diseases such as Huntington's disease and porphyria, primary or metastatic cancer of the brain, and endocrine disorders such as severe hypothyroidism, the symptoms of which are often referred to as "myxedema madness." In more recent centuries, additional medical causes of madness include infections such as advanced syphilis and exposure to toxins such as mercury used by hat makers, memorialized by Lewis Carroll's "Mad Hatter." 
Is there any estimate of the number of cases of madness, based on these known causes, which one would expect in a given population? This number would of course vary depending on the social circumstances, being higher, for example, after wars and famines. But one estimate of the prevalence of madness in history concluded that there was approximately one mad person for every 2000 people at any given time, or 0.5 cases per 1000 population point prevalence [36].

Given this background, what do we find when we look for cases of madness in history? We find occasional cases scattered throughout ancient texts, beginning with Mesopotamian clay tablets 5000 years old describing a man beset by "mischief makers" and "other evil machinations" suggesting paranoid delusions. The Old Testament also mentions madness several times. Deuteronomy 28 warns that "the Lord will smite you with madness and blindness and confusion of mind" if you break the commandments. In Daniel 4 Nebuchadnezzar is described as having a period of madness, then recovering. And Ezekiel was said to have experienced both auditory and visual hallucinations [37].

Occasional cases of madness were also described in ancient Greece and Rome. The cause of madness was usually attributed to disturbances of the humors, as described by Galen, although it was acknowledged that the gods could also cause madness. Herodotus, a Greek historian, described King Cleomenes of Sparta who exhibited bizarre behavior and committed suicide. Plutarch, a Greek biographer, recounted the bizarre behavior of a man who pretended to be Alexander the Great and attributed it to madness. Horace, a Roman poet, described a man who spent much time sitting in an empty theater applauding actors on an empty stage. Celsus, a Greek philosopher, described three different kinds of madness. Madness was also used by Greek writers and playwrights. Homer had Ajax become mad and Odysseus feign madness. Euripides had Orestes, who was being pursued by the Furies, briefly experience delusions and hallucinations [37, 38].

In reviewing these descriptions of madness in ancient literature, two aspects stand out. First, most cases are relatively brief, accompanied by fever or other medical symptoms, and followed by recovery. The symptoms of the madness described are consistent with infections of the brain and other medical causes of psychosis as described above. Second, the total number of cases of madness described in ancient texts is relatively few. This was emphasized by Katie Evans and her Australian colleagues who conducted an exhaustive search of Greek and Roman literature from the fifth century BCE to the middle of the second century CE. The search resulted in what they called "a handful of descriptions of psychotic symptoms" [38].

Now that we have established that infectious agents can be transmitted from animals to humans and have also established that infectious agents can cause psychosis, we can proceed to examine Toxoplasma gondii. 


\section{References}

1. Torrey EF, Yolken RH. Beasts of the earth: animals, humans and disease. New Brunswick: Rutgers University Press; 2005.

2. Taylor LH, et al. Risk factors for human disease emergence. Philos Trans R Soc Lond Ser B. 2001;356:983-9.

3. ProMED-mail. Avian influenza, human, East Asia. January 29, 2004.

4. Sink M. Colorado: pets as companions. New York Times, February 11, 2003.

5. Dewey C. Advocates petition USDA to extend food stamps to pets. Washington Post, January 24, 2018.

6. Brulliard K. How the chaos of hurricane Katrina helped save pets from the Texas floods. Washington Post, September 1, 2017.

7. Haag M. Company's new pet owners get 'fur-ternity leave. Washington Post, August 21, 2018.

8. Spending on pets surpasses $\$ 60$ Billion. JAVMA News. https://www.avma.org/News/ JAVMANews/Pages/160515g.aspx.

9. Chomel BB, Sun B. Zoonoses in the bedroom. Emerg Infect Dis. 2011;17:167-72.

10. Wikipedia, entry for Garfield. https://en.wikipedia.org/wiki/Garfield.

11. Vocelle LA. Revered and reviled: a complete history of the domestic cat. Great Cat Publications; 2016. p. 329.

12. Wikipedia, entry for Cats and the Internet.https://en.wikipedia.org/wiki/Cats_and_the_Internet.

13. Lopez C. Why is the Internet obsessed with cats? https://petlifetoday.com/why-is-theinternet-obsessed-with-cats/.

14. Victor D. Grumpy cat, online symbol of surly living, is dead at 7. New York Times, May 18, 2019.

15. Thanks to Dr. Marie McIntyre for providing an analysis of data from the Enhanced Infectious Diseases (EID2) database. The EID2 is an open-access resource developed by a group including M. Baylis (P.I), K.M. McIntyre and M. Wardeh at the University of Liverpool; for more information see https://eid2.liverpool.ac.uk.

16. Lappin MR. Feline zoonotic diseases. Vet Clin N Am Small Anim Pract. 1993;23:57-78.

17. Zangwell KM, et al. Cat scratch disease in Connecticut. N Engl J Med. 1993;329:8-12.

18. Halfmann PJ, et al. Transmission of SARS-CoV-2 in domestic cats. N Engl J Med. 2020;383:592-4. https://doi.org/10.1056/NEJMc2013400.

19. Bosco-Lauth AM, et al. Experimental infection of domestic dogs and cats with SARSCoV-2: pathogenesis, transmission, and response to reexposure in cats. Proc Natl Acad Sci. 2020;117(42):26382-8. https://doi.org/10.1073/pnas.2013102117.

20. Fritz M, et al. High prevalence of SARS-CoV-2 antibodies in pets from COVID-19+ households. One Health (Amsterdam, Netherlands). 2021;11:100192. https://doi.org/10.1016/j. onehlt.2020.100192.

21. Driscoll CA, et al. The Near Eastern origin of cat domestication. Science. 2007;317:519-23. https://doi.org/10.1126/science.1139518.

22. Rogers KM. Cat. London: Reaktion Books; 2006. p. 11-2.

23. Zeuner FE. A history of domesticated animals. London: Hutchinson; 1963. p. 391.

24. Engels D. Classical cats: the rise and fall of the sacred cat. New York: Rutledge; 1999. p. 93.

25. Torrey EF. Functional psychoses and viral encephalitis. Integr Psychiatry. 1986;3:224-36.

26. Severance EG, et al. Coronavirus immunoreactivity in individuals with a recent onset of psychotic symptoms. Schizophr Bull. 2011;37:101-7. https://doi.org/10.1093/schbul/sbp052.

27. Watson CJ, et al. COVID-19 and psychosis risk: real or delusional concern? Neurosci Lett. 2021;741:135491. https://doi.org/10.1016/j.neulet.2020.135491.

28. Miller BJ, Goldsmith DR. Evaluating the hypothesis that schizophrenia is an inflammatory disorder. Focus (American Psychiatric Publishing). 2020;18(4):391-401. https://doi.org/10.1176/ appi.focus.20200015. 
29. Rantakallio P, et al. Association between central nervous system infections during childhood and adult onset schizophrenia and other psychoses: a 28 -year follow-up. Int J Epidemiol. 1997;26:837-43.

30. Benros ME, et al. Autoimmune diseases and severe infections as risk factors for schizophrenia: a 30-year population-based register. Am J Psychiatry. 2011;168:1303-10.

31. Muller N. Inflammation in schizophrenia: pathogenetic aspects and therapeutic considerations. Schizophr Bull. 2018;44:973-82.

32. Corvin A, Morris DW. Genome-wide association studies: findings at the major histocompatibility complex locus in psychosis. Biol Psychiatry. 2014;75:276-83.

33. Davison K, Bagley CR. Schizophrenia-like psychoses associated with organic disorders of the central nervous system: a review of the literature. In: Herrington RN, editor. Current problems in neuropsychiatry. Ashford, Kent: Hedley; 1969. p. 113-84.

34. Shukla GD, et al. Psychiatric manifestations in temporal lobe epilepsy: a controlled study. $\mathrm{Br}$ J Psychiatry. 1979;135:411-7.

35. Achte KA, Hillborn E, Aalbreg V. Psychoses following war brain injuries. Acta Psychiatr Scand. 1969;45:1-18.

36. Torrey EF, Miller J. The invisible plague: the rise and fall of mental illness from 1750 to the present. New Brunswick: Rutgers University Press; 2002. p. 343.

37. Jeste DV, et al. Did schizophrenia exist before the eighteenth century? Compr Psychiatry. 1985;26:493-503.

38. Evans K, et al. Searching for schizophrenia in ancient Greek and Roman literature: a systematic review. Acta Psychiatr Scand. 2003;107:323-30.

Open Access This chapter is licensed under the terms of the Creative Commons AttributionNonCommercial-NoDerivatives 4.0 International License (http://creativecommons.org/licenses/ by-nc-nd/4.0/), which permits any noncommercial use, sharing, distribution and reproduction in any medium or format, as long as you give appropriate credit to the original author(s) and the source, provide a link to the Creative Commons license and indicate if you modified the licensed material. You do not have permission under this license to share adapted material derived from this chapter or parts of it.

The images or other third party material in this chapter are included in the chapter's Creative Commons license, unless indicated otherwise in a credit line to the material. If material is not included in the chapter's Creative Commons license and your intended use is not permitted by statutory regulation or exceeds the permitted use, you will need to obtain permission directly from the copyright holder. 